\title{
A születési súlyok megoszlása 2011 és 2015 között és a percentilisértékek változása 1996 és 2015 között
}

\author{
A Tauffer-adatbázis feldolgozása \\ Zsirai László dr. ${ }^{1}$. Csákány M. György dr. ${ }^{2}$ \\ Végh György dr. ${ }^{3}$. Tabák Gy. Ádám dr. ${ }^{4,5}$ \\ ${ }^{1}$ Istenhegyi Géndiagnosztikai és Családtervezési Centrum, Budapest \\ ${ }^{2} J a h n$ Ferenc Kórház, Szülészeti és Nőgyógyászati Osztály, Budapest \\ ${ }^{3}$ Szent János Kórház és Észak-budai Egyesített Kórházak, Szülészeti és Nőgyógyászati Osztály, Budapest \\ ${ }^{4}$ Semmelweis Egyetem, Általános Orvostudományi Kar, I. Belgyógyászati Klinika, Budapest \\ ${ }^{5}$ University College London, Epidemiológiai és Népegészségtani Tanszék, London, Egyesült Királyság
}

\begin{abstract}
Bevezetés és célkitüzés: Kutatási célunk a 2011 és 2015 közötti magyarországi szülések feldolgozásának segítségével gesztációs hetekre, nemekre, valamint egyes és többes terhességből született magzatokra bontott aktuális percentilistáblázat megalkotása. Emellett vizsgáltuk, hogy 1996 és 2015 között ötéves periódusokban hogyan változtak gesztációs hetenként az egyes és iker fiú- és leánymagzatok átlag születési súlyai.

Módszer: A Magyarországon kötelezően kitöltendő és vezetett Tauffer-statisztika 2011 és 2015 közötti adatai alapján minden gesztációs héthez kiszámoltuk az 5, 10, 25, 50, 75, 90 és 95 percentilisértéket nemenként, egyes és ikerterhességek esetén. Vizsgáltuk továbbá a születési súlyok terhességi hetenkénti változását 1996 és 2015 között ötéves periódusokban.

Eredmények: A 2011 és 2015 közötti élveszületések súly-percentilisértékeit grafikusan ábrázoltuk, és táblázatokban is összefoglaltuk. A vizsgált 20 év alatt az egyes terhességekben a 35-4l. héten a születési súly 2011-2015-höz viszonyítva az 1996-2005-ig terjedő időszakban alacsonyabb volt (a legalacsonyabb 1996-2000-ben), míg a 2006-2010-es periódusban magasabb vagy hasonló volt (például a 38. héten a fiúknál 2011-2015-ben az átlagsúly 3249 g, $1996-$ 2000-ben 34,3 [SE 3,0] g-mal, 2001-2005-ben 11,5 [2,9] g-mal kevesebb, 2006-2010-ben 18,1 [2,9] g-mal több). Az ikerterhességekben hasonló, de nem egyértelmű tendenciát figyeltünk meg a 35-38. heti születési súlyokban.

Következtetés: Tekintettel a születési súlyok elmúlt 20 évben megfigyelt jelentős változására, szükséges az általában használt percentilistáblázat megújítása. A születési súlyok 1996 és 2010 között növekedtek, elsősorban az érett magzatok esetén, az ezt követő periódusban csökkenő vagy stagnáló tendencia figyelhető meg.

Orv Hetil. 2019; 160(36): 1426-1436.
\end{abstract}

Kulcsszavak: terhesség, várandósság, szülészeti adatbázis, Tauffer-statisztika, születésitesttömeg-percentilis, ikerterhesség

\section{Distribution of birth weights between 2011 and 2015 and changes in percentile figures between 1996 and 2015}

\section{Analyis of the Tauffer database}

Introduction and aim: We aimed to provide a current birth weight percentile table for singleton and twin pregnancies stratified by gestational week at delivery and sex using data from all live births in Hungary between 2011 and 2015. In addition, we examined temporal trends in average birth weights in singleton and twin pregnancies by sex in fiveyear periods between 1996 and 2015 . 
Method: We calculated the 5th, 10th, 25th, 50th, 75th, 90th, and 95th centiles of birth weight for each gestational week by sex for singleton and twin pregnancies using compulsory collected obstetrical data (Tauffer Statistics) in Hungary in 2011-2015. Furthermore, we described changes in birth weights by gestational week between 5-year periods from 1996 to 2015.

Results: We present birth weight centiles for live births in both tabular and graphical forms using data from 2011 to 2015. In general, live birth weights in gestational weeks 35-41 were lower in the period of 1996-2005 (the lowest in 1996-2000) and were higher in the period of 2006-2010 compared to the reference period of 2011-2015 (e.g., the average male newborn weighed $3249 \mathrm{~g}$ at gestational week 38 in 2011-2015, which is 34.3 [SE at 3.0] g less in 1996-2000, 11.5 [2.9] g less in 2001-2005, and 18.1 [2.9] g more in 2006-2010). Similar trends were not observed in birth weights of twin pregnancies in gestational weeks 35-38.

Conclusion: Given the observed substantial change in birth weights during the past 20 years, renewal of the commonly used percentile tables is necessary. Birth weights increased from 1996 to 2010, mainly of mature newborns, followed by a stabilization or slight decrease in the later periods.

Keywords: birth weight percentile, birth weight standards, birth weight temporary trend, twin pregnancy

Zsirai L, Csákány MGy, Végh Gy, Tabák GyÁ. [Distribution of birth weights between 2011 and 2015 and changes in percentile figures between 1996 and 2015. Analyis of the Tauffer database]. Orv Hetil. 2019; 160(36): 1426-1436.

(Beérkezett: 2019. március 15.; elfogadva: 2019. április 28.)

\section{Rövidítések}

$\mathrm{AGA}=$ (appropriate for gestational age $)$ a terhességi kornak megfelelő; BMI = (body mass index $)$ testtömegindex; CRL = (crown-rump length) kora terhességi ülésmagasság; $\mathrm{CI}=$ (confidence interval) konfidenciaintervallum; IQR = (interquartile range) interkvartilistartomány; LGA $=$ (large for gestational age) túlzott magzati növekedés; $\mathrm{SE}=$ (standard error) standard hiba; SGA = (small for gestational age) alacsony születési súlyú

A születési súly az újszülött általános állapotának egyik első markere, amely szoros összefüggésben van az újszülött-morbiditással és -mortalitással. Abnormális születési súly esetén fokozott a perinatalis mortalitás a normál születési súlyhoz képest [1]. A neonatalis állapot rizikóbecslése tovább javítható a születési súly gesztációs korra történő igazításával (percentilisadatok). Ennek használata alkalmas lehet a perinatalis szövődmények, valamint a morbiditás és mortalitás csökkentésére. Ismert, hogy a nagyobb ( $\geq 90$ percentilis) és az alacsonyabb ( $\leq 10$ percentilis) születési súllyal rendelkező magzatok perinatalis morbiditása és mortalitása nagyobb a normálsúlyúakhoz képest [2].

A magyar születési súlyok feldolgozását először $K e ́ z-$ márszky Tivadar, a Budapesti Szülészeti Klinika igazgatója végezte el 1873-ban [3]. Ezt követôen a XX. század elején Kontsek Béla 1000 debreceni újszülött részletes antropometriai méreteit dolgozta fel. Ez az elemzés azért is különösen fontos, mert nem csupán a testfejlettség és -tápláltság megítéléséhez használta fel a születési méreteket, hanem - Magyarországon elsóként - a várandóssági sorrenddel, a szülők életkorával, az anya testmagasságával és a szociális körülményekkel összefüggésben is elemezte azokat [4].

Az első nemzetközi testtömegstandardok kidolgozása Lubchenco nevéhez füződik [5], aki később Battagliával együtt a születéskori testtömegstandardok alapján vezette be a 10-90 percentilis közöttiek esetén a normális (birth weight appropriate for gestational age; AGA), a 10 percentilis alattiak esetén az alacsony (birth weight small for gestational age; SGA) és a 90 percentilis felettiek esetén a nagy (birth weight large for gestational age; LGA) súlyú magzat elnevezés használatát [6]. Ezt követően Magyarországon is számos közlemény jelent meg az újszülöttstandardok feldolgozásával kapcsolatban [7$11]$.

Kiemelendő ezek közül Papp Zoltán és munkacsoportjának feldolgozása, amelyben Kelet-Magyaroszágra specifikus súlypercentiliseket írtak le [12], alapot szolgáltatva egy későbbi összehasonlító feldolgozáshoz [13]. $\mathrm{Az}$ országos Tauffer-adatbázis egy korábbi elemzését Csákány és mtsa publikálta 1998-ban [14].

A Központi Statisztikai Hivatal adatainak rendszeres és több évre kiterjedő feldolgozása Joubert Kálmán nevéhez kötődik. Számos szülész-nőgyógyásszal és neonatológussal együtt szorgalmazta, hogy az újszülöttek állapotfelmérésekor ne csak a születési súlyt, hanem a gesztációs korhoz viszonyított súlypercentilist használják $[11,15,16]$. A születési súlyoknak az utóbbi évtizedekben bekövetkezett változása szükségessé teszi a súlypercentilis-adatok (gesztációs hét és nem szerint stratifikált) rendszeres frissítését. Ez különösen azért is fontos, mert az utóbbi évtizedekben az anyai életkor és testsúly is jelentősen növekedett $[17,18]$.

Vizsgálatunk célja volt, hogy a jelenlegi magyar (2011-2015) populációt jellemző percentilisstandardokat alkossunk a Tauffer-adatbázis alapján. Emellett 1996-tól 2015-ig elemeztük a születési súlyok változását, referenciának tekintve az utolsó 5 évet. Feltételezve, hogy a születési súlyok az utóbbi húsz évben nem változtak, vizsgálatunk ennek bizonyítására vagy cáfolására is irányult. 


\section{Módszer}

\section{Adatbázis}

Elemzésünkhöz a Magyarországon kötelezően kitöltendő, egységesített szülészeti adatbázist használtuk, amelyet 1930-ban Tauffer Vilmos vezetett be. A szülések utáni kötelező adatgyüjtés megszervezését 1993-ban a Szülészeti és Nőgyógyászati Intézet, jelenleg az Állami Egészségügyi Ellátó Központ végzi. Az adatgyưjtés anonim, és emiatt nem azonosíthatók az egyes terhesek ismételt szülései. Az adatbázis leírását és adataink validálását korábbi közleményünk tartalmazza [19].

\section{Betegek és módszer}

A Tauffer-adatbázisban 1996 és 2015 között 1748360 szülés szerepel. Ezek közül töröltük azokat az eseteket, amelyekben a születési súly és az újszülött neme jelöletlen volt, így maradt 1745757 szülés (1. ábra). Ebből egyes szülés 1717822 (élve született 1765929 magzat - 96,82\%), kettes ikerszülés 27105 (élve született 53669 magzat - 3,04\%), hármas ikerszülés 816 (élve született 2407 magzat - 0,14\%), négyes ikerszülés 14 (élve született 54 magzat - 0,003\%). Az egyes terhességek közül élve született 1709799 magzat, ikerterhességekből 53669 magzat.
Az összes élve született magzat számát összehasonlítva a Központi Statisztikai Hivatal élveszületési adataival (1 909 913), az adatbázis az összes hazai élveszületés 92,46\%-át tartalmazza [20, 21].

Mivel a súlypercentilisek a magzati nemre és gesztációs hétre igazítottak, ezen adatok bármelyikének hiánya esetén az esetet kizártuk a feldolgozásból. Az adatbázis tisztítása során kizártuk az extrém születési súlyokat: medián $\pm 2 \times$ interkvartilistartományon (IQR) kívül eső érték. Így végül 1685532 egyes és 52448 kettes iker élveszületés került a vizsgálatba. Az aktuális percentilisértékek megadásához a 2011 és 2015 közötti öt év 418664 egyes és 13674 ikerterhességből született magzat - adatait elemeztük.

\section{Változók}

A gesztációs hét a várandósság időtartamát jelöli az utolsó menstruációtól számítva hetekben. Az ultrahangkor azonban bizonyos esetekben eltérhet a Naegele-számítástól. Az ultrahangvizsgálatok elterjedése óta számos publikáció [22] jelent meg arról, hogy a kora terhességi ülőmagasság (CRL) értéke pontosabban mutatja a gesztációs kort, azonban nemzetközi és hazai protokoll csak jóval később született $[23,24]$. Az anyai életkor az anya szülési és születési idejének különbsége években. A magzat születési súlya a szülőszobán kerül meghatározásra grammban rögzítve. A magzat nemének meghatározása a

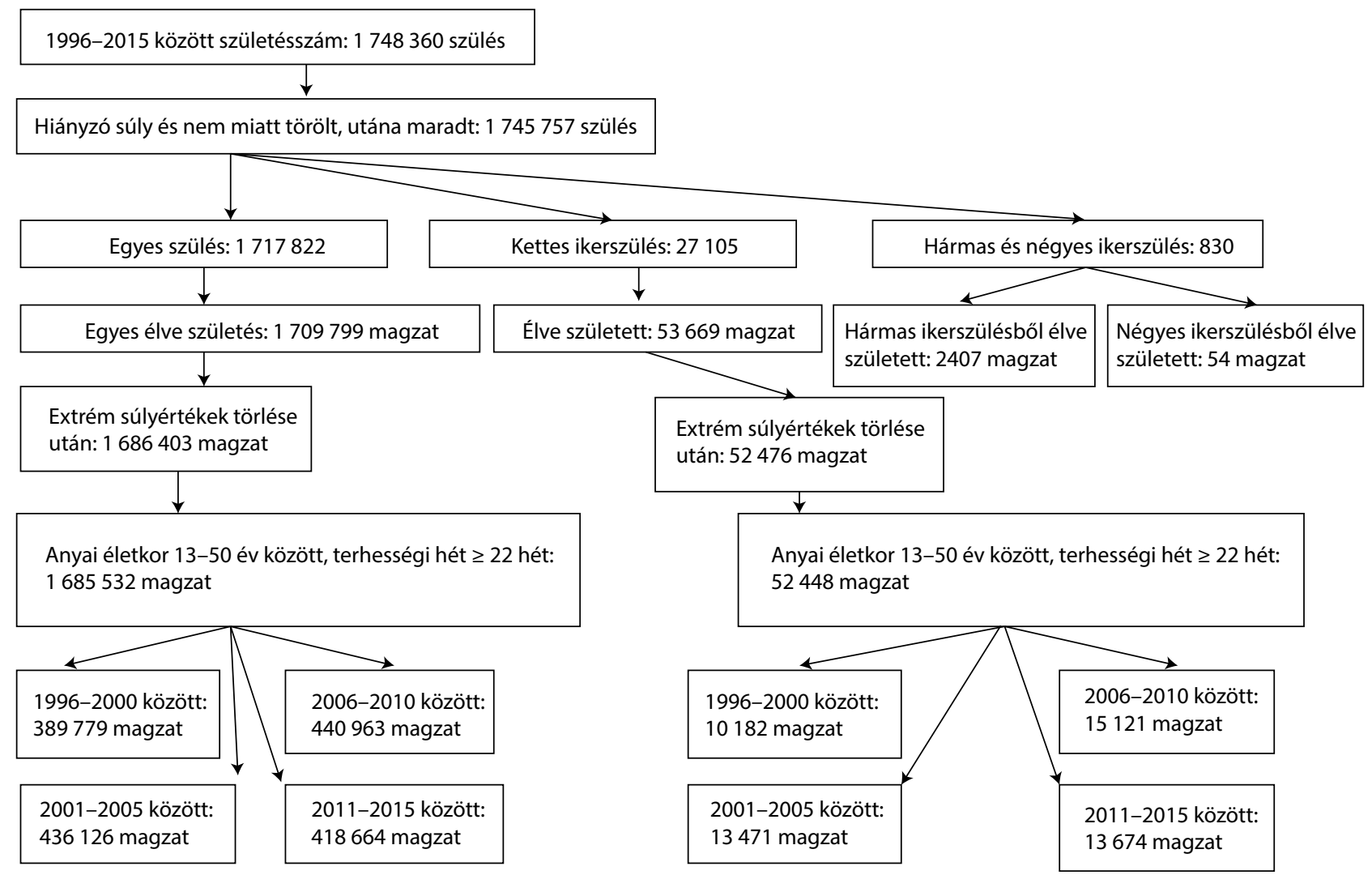

1. ábra | A vizsgálatba bevont újszülöttek kiválasztásának folyamatábrája 
szülés után közvetlenül, a külső nemi jelleg alapján történik. Az adatbázis nem tartalmaz adatot arról, ha a nem a késôbbiekben módosítva lett (interszexuális kórképek).

\section{Statisztikai analizis}

Az aktuális (2011 és 2015 közötti) időszak magzati születési súlyait gesztációs hetenként átlag, szórás és 95\%-os konfidenciaintervallum (95\% CI) vagy medián és 5, 10 , 25, 75, 90 és 95 percentilis formájában grafikonon ábrázoltuk. A 22. és 43. heti kis esetszámok miatt a 22-23. hetet és a 42-43. hetet összevonva elemeztük. A kettes ikrek esetében ugyanígy jártunk el, ott a 22-23. hét mellett a 40-41. hetet vontuk össze (a 42-43. héten ikerszülés nem volt).

A temporális trendek vizsgálatakor a 2011 és 2015 közötti ötéves időszakot referenciaperiódusnak tekintettük. Ehhez hasonlítottuk az 1996 és 2000, 2001 és 2005 és 2006 és 2010 közötti időszakok születési súlyait. Az egyes gesztációs hetekre nemenként általános lineáris modelleket építettünk, amelyek kimenetele a születési súly, független változói az egyes ötéves időszakok voltak. Az átlag születési súlyok mellett a referencia-időszak születési súlyaitól való eltérést, ennek standard hibáját (SE), valamint a heterogenitási p-értéket adtuk meg. A feldolgozáshoz az SPSS 20.0 verziójú programot (IBM Corporation, Armonk, NY, Amerikai Egyesült Államok) használtuk, a kétoldalú $\mathrm{p}<0,05$ értéket tekintettük statisztikailag szignifikánsnak.

\section{Eredmények}

Egyértelmű különbség állapítható meg a két nem között az egyes gesztációs hetekben (2. és 3. ábra). Az átlag születési súly a fiúknál nagyobb. A születési súlyok gesztációs hetenkénti alakulását mutató görbék exponenciális jellegűek. A fiúk esetében a percentilisgörbe meredekebb, a lányoknál inkább kissé laposabb (például a fiúk mediánja 555 g-ról 3650 g-ig, a lányok mediánja 525 g-ról 3518 g-ig emelkedik). A 40. gesztációs héttől a születési súlyok növekedése lassul, a 4l. héttől inkább stagnál; az alacsony percentilisek esetén csökken a születési súly.

A kettős ikerterhességek esetén a görbe közel ugyanarról a súlyról indul, mint az egyes terhességeknél (a fiúk mediánjának esetén 550 g, a lányoknál 490 g), azonban alacsonyabb értékig emelkedik (a fiúk mediánjának esetén 2928 g-ig, a lányoknál 2775 g-ig), és a görbe alakja is inkább lineáris jellegü (4. és 5. ábra). A születési súlyok emelkedése a 39. hétig egyenletes, a 39. héttől fiúknál a 95, lányoknál pedig a 90 percentilisek esetén csökken a születési súly. A görbék alakja mindkét nem esetében az egyes terhességekhez képest kevésbé kiegyenlített, elsősorban a kisebb esetszámok miatti nagyobb bizonytalanság miatt.

A várandóssági súlyok temporális trendjének (1996 és 2015 között) vizsgálatakor a 2011 és 2015 közötti referencia-időszakhoz hasonlítottuk az átlagos születési súlyokat az 1996 és 2000, a 2001 és 2005 és a 2006 és 2010 közötti ötéves periódusokban.

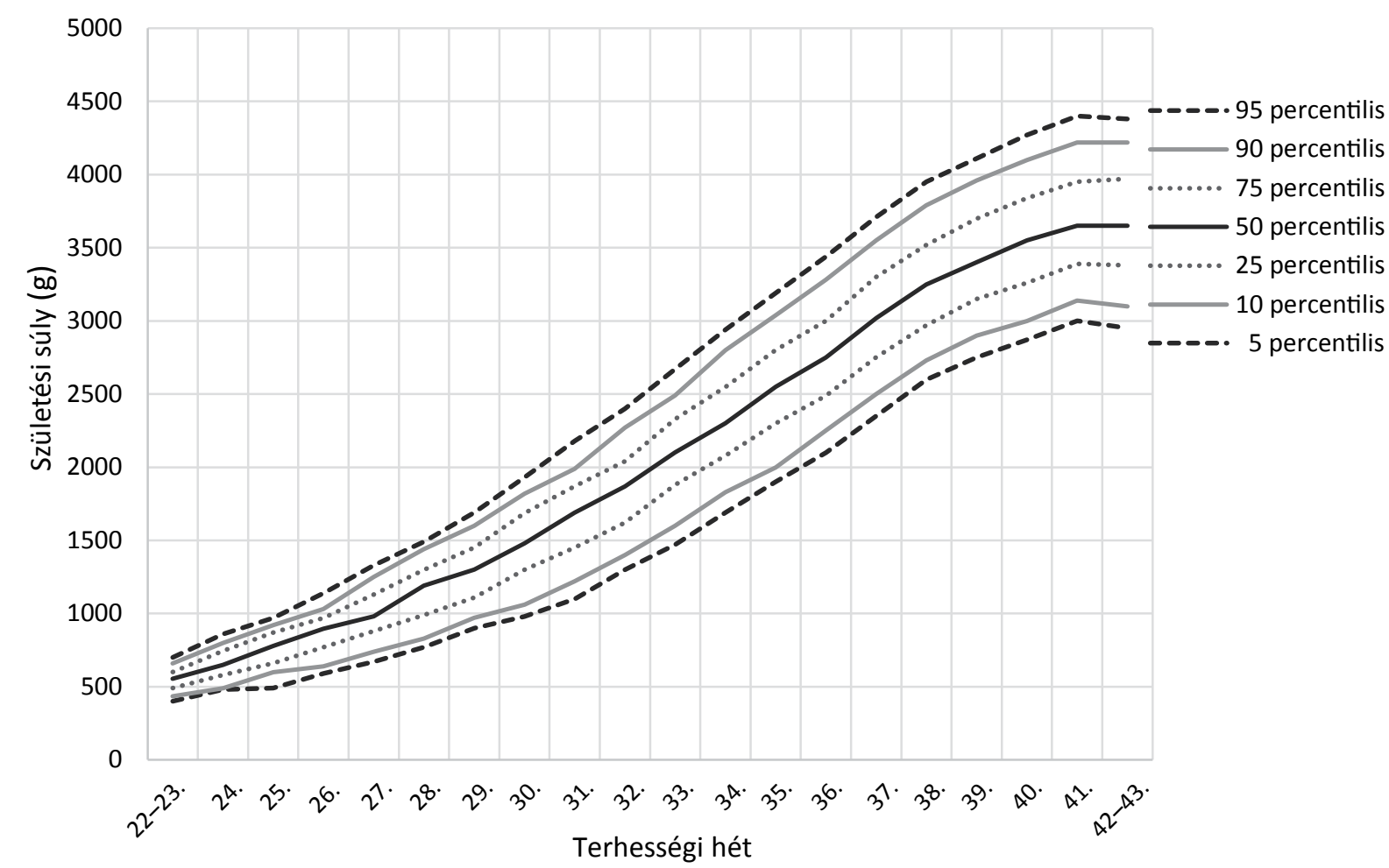

2. ábra $\quad$ Egyes terhességekből született fiúk születéskori testtömeg (g)-referenciapercentilisei a terhességi hét függvényében a 2011-2015. évi országos születési adatok alapján. 


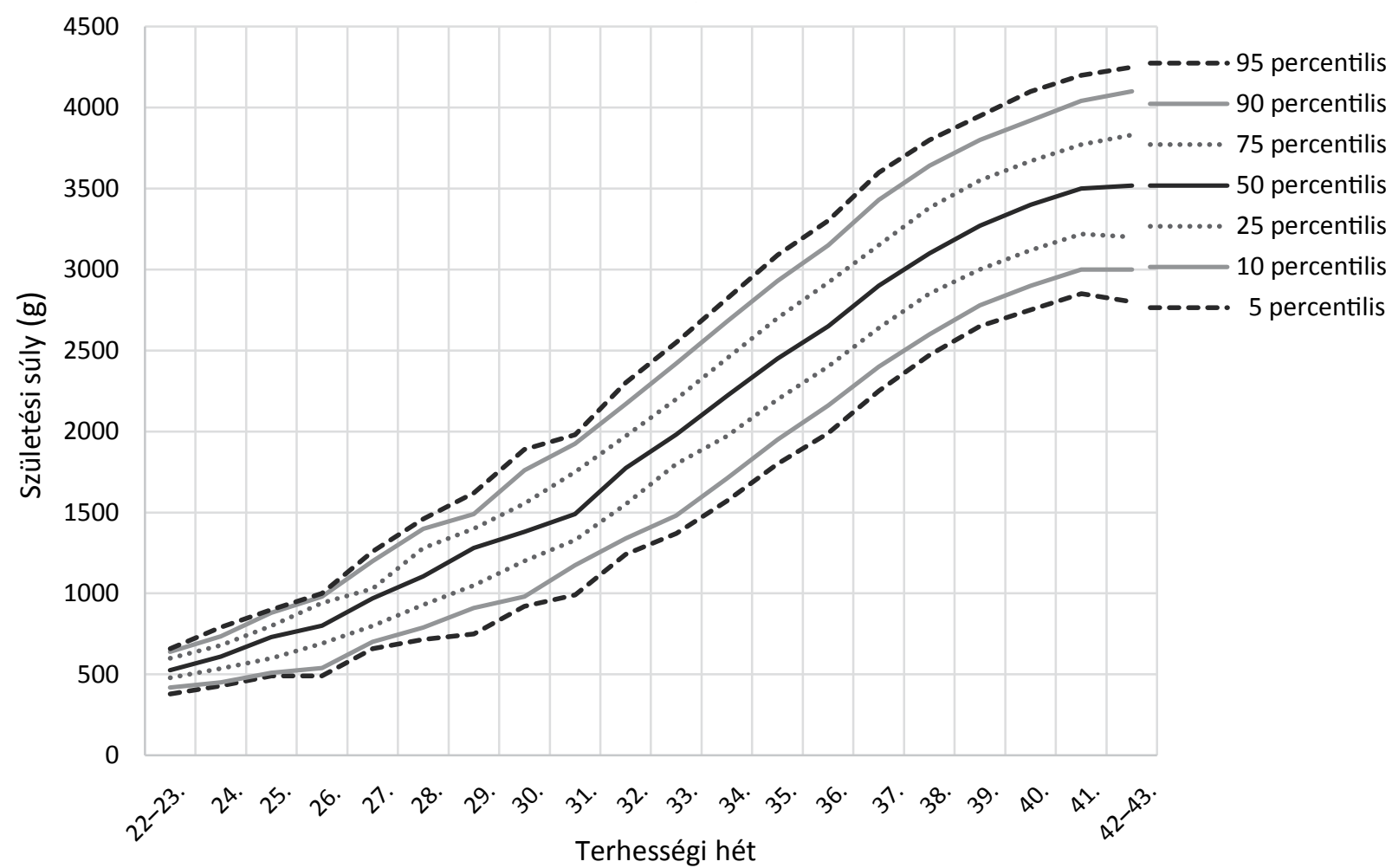

3. ábra $\quad$ Egyes terhességekből született lányok születéskori testtömeg (g)-referenciapercentilisei a terhességi hét függvényében a 2011-2015. évi országos születési adatok alapján

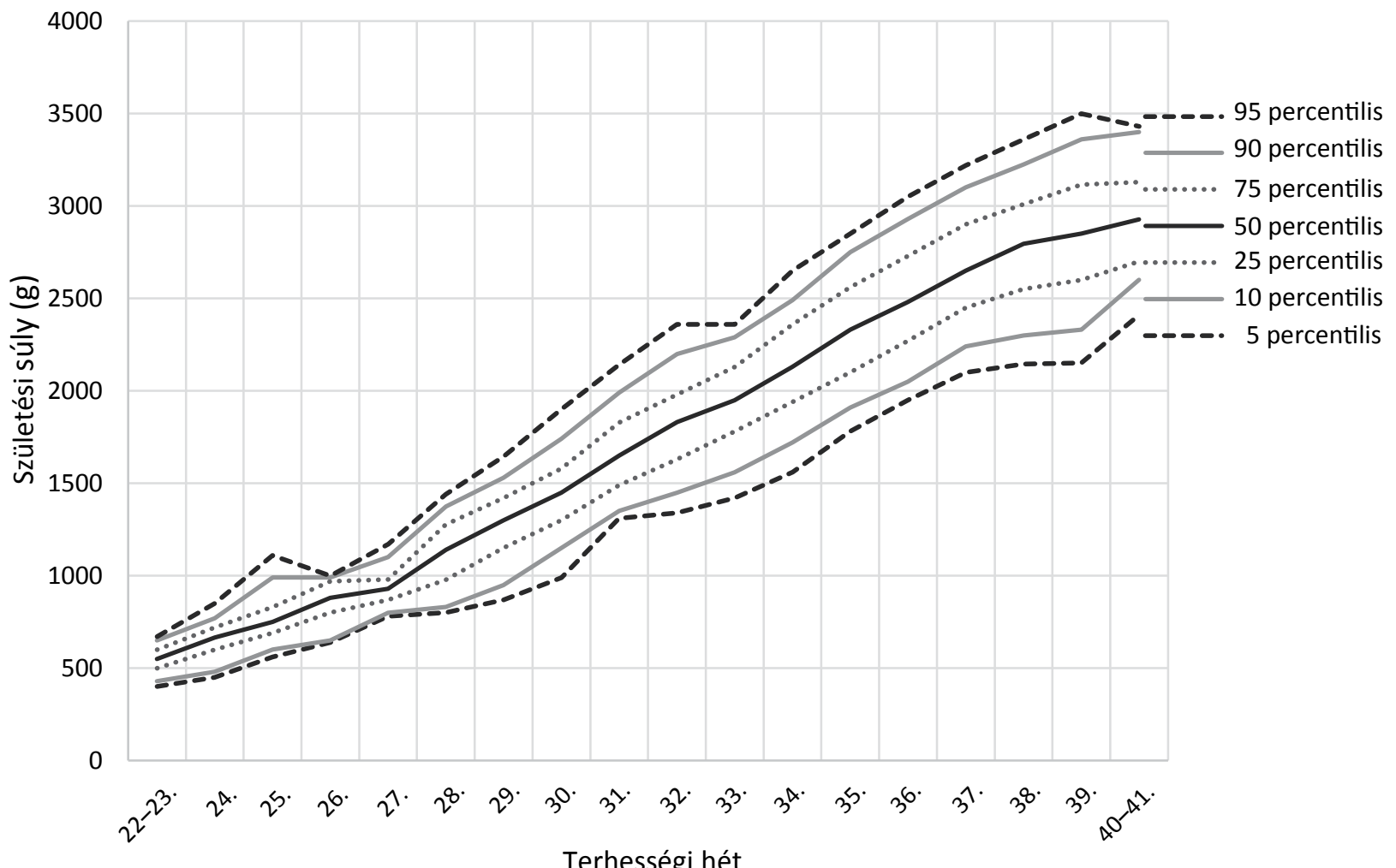

4. ábra $\quad$ Kettes ikerterhességekből született fiúk születéskori testtömeg (g)-referenciapercentilisei a terhességi hét függvényében a 2011-2015. évi országos születési adatok alapján 


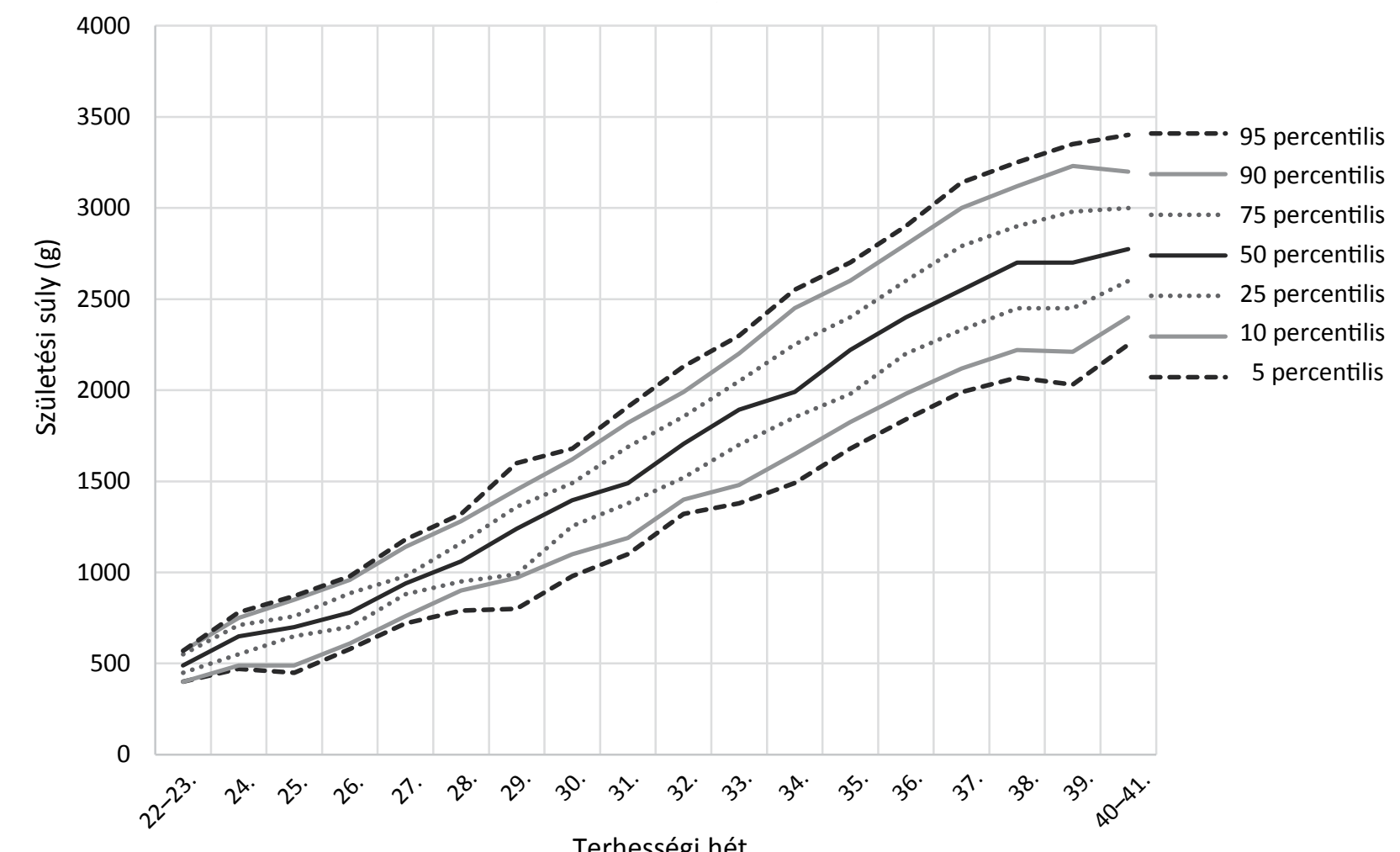

5. ábra

Kettes ikerterhességekből született lányok születéskori testtömeg (g)-referenciapercentilisei a terhességi hét függvényében a 2011-2015. évi országos születési adatok alapján

A fiúknál a vizsgált 20 éves idôszakban a születési súlyok statisztikailag szignifikáns heterogenitása figyelhetó meg a 30. és a 33-41. héten. Amennyiben az ötéves periódusokat egyenként vizsgáljuk, nem minden periódus különbözik a referencia- (2011 és 2015 közötti) időszaktól. A 37., 38. és 39. heti születési súlyok minden vizsgált időszakban eltérnek a referencia-időszak értékeitől. Ezekben a gesztációs hetekben az 1996 és 2000 közötti és a 2001 és 2005 közötti születési súlyok alacsonyabbak, ezzel ellentétben a 2006 és 2010 közötti átlag születési súlyok magasabbak a referencia-idôszakhoz viszonyítva. Mindezek alapján úgy túnik, hogy a születési súlyok 2010-ig nőttek, majd csökkentek. A 38. héten például a születési súly 3214 g-ról 3267 g-ra emelkedett, majd 3249 g-ra csökkent (6. ábra).

A lányok esetén a vizsgált 20 éves időszakban a születési súlyok statisztikailag szignifikáns heterogenitása figyelhető meg a 24., a 26., a 28. és a 35-43. héten. A 36-38. gesztációs héten mért születési súlyok minden vizsgált ötéves periódusban statisztikailag eltértek a referenciaperiódusban megfigyelttől (például a 38. gesztációs héten a születési súly 3080 g-ról 3128 g-ra emelkedett 1996 és 2010 között, majd 2011-2015-re enyhén csökkent, 3115 g-ra) (6. ábra).

Ikerterhességeknél a fent említett összefüggések nem teljesen egyértelmúek. A születési súlyok heterogenitása igazolható a 35-38. gesztációs héten, azonban ezek iránya nem mindig konzekvens. A születési súlyok növeke- dése ugyanakkor mind a fiúk, mind a lányok esetén igazolható a 35-37. gesztációs héten 1996-2000 és 2011-2015 között.

\section{Megbeszélés}

Kutatásunk során a hazai korszerú szülészeti igényeknek megfelelő új percentilisadatokat alkottunk. A fiúk átlag születési testtömege magasabb a lányokénál, a terminushoz közelítve a két nem közötti különbség növekszik. Az egyes terhességekben a percentilisgörbe alakja inkább exponenciális, ikrek esetében inkább lineáris jellegú.

\section{Egyes szülések korábbi magyar adatai}

Joubert ismételt vizsgálatokban (1973 és 1978 között [11], 1990 és 1996 között [15] és 2000 és 2012 között [16]) elemezte a születésisúly-percentiliseket. Az éretlen koraszülöttek medián ( 50 percentilis) testtömegét vizsgálva mind a fiúk, mind a lányok testtömege (a 24 . héten fiú/lány: 1973-1978-ban 866/831 g, 1990-1996-ban $700 / 655 \mathrm{~g}, 2000-2012-b e n$ 673/638 g, saját adatunk 2011-2015-ben 650/610 g, a 28. héten: 1973-1978ban 1357/1321 g, 1990-1996-ban 1155/1100 g, 2000-2012-ben $1175 / 1116$ g, saját adatunk 20112015-ben 1195/1105 g) lényegesen magasabb 1973 1978-ban, mint a késóbbi időszakokban. A 24. heti születési súlyok a teljes vizsgált periódusban csökkenést 


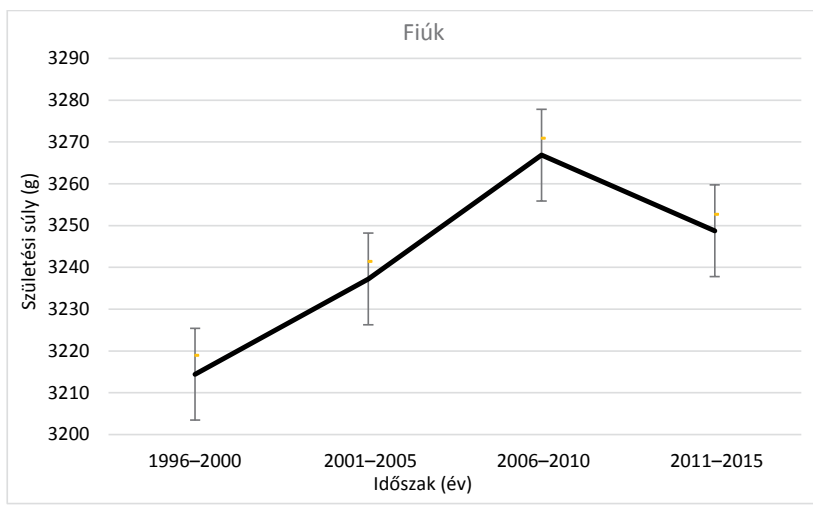

B

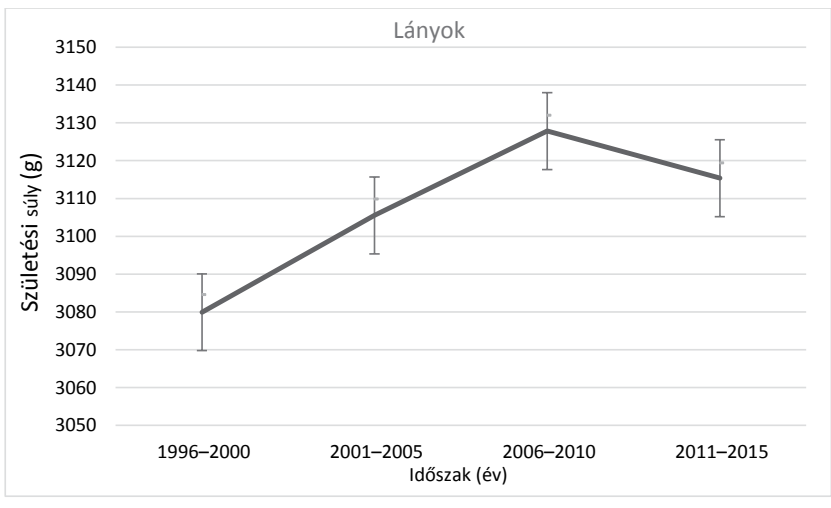

A hibasávok a 95\%-os konfidenciatartományokat jelölik.

6. ábra

A 38. terhességi hétre született, egyes szülött fiúk (A) és lányok (B) élveszületési testtömeg (g)-adatainak alakulása 1996 és 2015 között ötéves periódusokban

mutatnak, ami valószínúleg a pontosabb adatfelvételnek (a gesztációs hét pontosabb becslése), illetve adatkitöltésnek és nem a csökkenő születési súlyoknak köszönhető. A 28. gesztációs héten már csak az első (1973-1978 közötti) időszak tér el jelentősen a legutolsó időszaktól, itt is feltételezhetően már pontosabb az adatok jelentése. A mi adatainkhoz leginkább a 2000-2012-es időszak adatai közelítenek.

A későbbi koraszülöttek (32. hét fiú/lány: 1954/1949 g, $1850 / 1800 \mathrm{~g}, 1904 / 1822 \mathrm{~g}$, saját $1870 / 1775 \mathrm{~g}$ és 36. hét fiú/lány $2746 / 2657 \mathrm{~g}, 2720 / 2620 \mathrm{~g}$, $2798 / 2868 \mathrm{~g}$, saját $2750 / 2650 \mathrm{~g}$ ), valamint az érett újszülöttek (40. hét fiú/lány: 3373/3230 g, 3500/3340 g, 3555/3400 g, saját 3550/3400 g) születési testtömegei sokkal egyenletesebbek. A 32. héten 1973 és 1978 között még nagyobb a születési súly, mint a későbbi időszakokban, a 36. héttől azonban már sokkal jobban közelítenek egymáshoz a különböző időszakok értékei. A mi adatainkhoz nem meglepő módon a legjobban a 2000-2012 közötti időszak hasonlít. A görbék alakja az 1973 és 1978 közötti időszakban inkább lineáris, az 1990-1996 és 2000-2012 közötti időszakban a saját görbéinkhez hasonlóan inkább exponenciális jellegú.

\section{Egyes szülések adatai nemzetközi összehasonlitásban}

Egy multicentrikus, több országot magában foglaló tanulmányban (INTERGROWTH-21st, n = 20 486, 2009 és 2014 között) minden gesztációs héten alacsonyabb születési testtömegeket tapasztaltak, mint az általunk megfigyeltek (33. hét: fiú/lány 1950/1860 g vs. $2100 / 1980 \mathrm{~g}$, 36. hét: $2690 / 2600 \mathrm{~g}$ vs. $2750 / 2650 \mathrm{~g}$, 40 . hét $3380 / 3260 \mathrm{~g}$ vs. $3550 / 3400 \mathrm{~g}$ ). Mindez megkérdőjelezi ezen adatok magyarországi adaptálhatóságát [25].

Lengyel szerzők ugyanezen időszak (2011-2016) több mint 27000 újszülöttadatát feldolgozva a miénkhez hasonló medián adatokat publikáltak késői koraszülöttek és érett újszülöttek esetén (33. hét fiúk/lányok $2095 / 2001 \mathrm{~g}$ vs. saját $2100 / 1980 \mathrm{~g}, 36$. hét: $2885 / 2732 \mathrm{~g}$ vs $2750 / 2650 \mathrm{~g}$, 40 . hét $3676 / 3527 \mathrm{~g}$ vs. $3550 \mathrm{~g} / 3400 \mathrm{~g}$ ) [26]. Törökországban 2007 és 2013 között egy nagyobb vizsgálatban ( $n=68255$ újszülött) mind a koraszülöttek, mind az érett újszülöttek születési testtömegeinek trendje hasonló az általunk mértekhez, bár az eredményeinktőll való különbségek kifejezettebbek a lengyel adatokhoz viszonyítva (24. hét fiú/lány: 700/725 g vs. 650/610 g, 28. hét: 1110/1180 $\mathrm{g}$ vs. $1190 / 1105 \mathrm{~g}, 32$. hét: $1980 / 1840 \mathrm{~g}$ vs. $1870 / 1775 \mathrm{~g}$, 36 . hét: $2850 / 2780 \mathrm{~g}$ vs. $2750 / 2650 \mathrm{~g}$, 40. hét: $3370 / 3490 \mathrm{~g}$ vs. $3550 / 3400 \mathrm{~g}$ ) [27]. Az európai régióból még Spanyolországból állnak rendelkezésre nagyobb populációs minta adatai (2008-2011; $\mathrm{n}=$ 23578 újszülött). Meglepő módon a spanyol újszülöttek testtömege minden gesztációs héten nominálisan alacsonyabb a saját adatainkhoz képest (28. hét: fiú/lány 1044/1012 g vs. 1190/1105 g, 32 hét: 1724/1697 g vs. $1870 / 1775 \mathrm{~g}, 36$. hét: $2613 / 2534 \mathrm{~g}$ vs. $2750 / 2650$ g, 40. hét: $3379 / 3243$ g vs. $3550 / 3400$ g) [28]. A percentilisgörbék lefutása a vizsgált európai populációkban (a mi eredményeinkhez hasonlóan) inkább exponenciális jellegú.

Az Egyesült Államokban valamivel korábbi időszakban (1991 és 2011 között) végzett felmérés ( $\mathrm{n}=$ 3252011 ) adatai nagyon hasonlóak a saját eredményeinkhez (24. hét: $706 / 652 \mathrm{~g}$ vs. $650 / 610 \mathrm{~g}, 28$. hét: $1177 / 1102$ g vs. $1190 / 1105$ g, 32 . hét: 1871/1784 g vs. $1870 / 1775 \mathrm{~g}, 36$. hét $2846 / 2734 \mathrm{~g}$ vs. $2750 / 2650$ g, 40. hét: $3572 / 3431$ g vs. $3550 / 3400$ g) [29]. Egy kubai felmérés (2008 és 2012 között, $\mathrm{n}=16$ ezer újszülött) eredményei is hasonlóak a saját adatainkhoz (32. hét: $1945 / 1620 \mathrm{~g}, 36$. hét: $2640 / 2560 \mathrm{~g}, 40$. hét: $3450 / 3300 \mathrm{~g})$ [30].

A nagyrészt kaukázusi populációkban, fejlett országokban végzett felmérések adatai bár összességében hasonlóak a magyarországi adatokhoz, a terhespopuláció jellemzői így is jelentősen eltérhetnek a hazai lakosságéitól (BMI, életkor, szociális helyzet), ezért direkt alkalmazásuk szintén kérdéses. 
Ázsiai populációkban is publikáltak születési percentilisadatokat. A fejlett országok közé tartozó Dél-Koreában (2010 és 2012 között, $\mathrm{n}=1381088$ újszülött) a születési súlyok a terminust leszámítva nagyobbak a hazai magzatok születési súlyánál (24. hét: $720 / 669$ g vs. 650/610 g, 28. hét: $1232 / 1147$ g vs. 1190/1105 g, 32. hét: $1963 / 1861 \mathrm{~g}$ vs. $1870 / 1775 \mathrm{~g}, 36$. hét: $2805 / 2698$ g vs. $2750 / 2650$ g, 40 . hét: $3408 / 3292$ g vs. $3550 / 3400$ g) [31]. Ezzel ellentétben a fejlődő országnak minősülő India déli részén (1996 és 2010 között, $\mathrm{n}=41055$ újszülött) az elôször és a többedszer szülő nők magzatainak súlya is alacsonyabb az általunk talált születési súlyoknál (32. hét: 1630 g-1795/14261731 g vs. $1870 / 1175$ g, 36. hét: $2472-2600 / 1393-$ $2511 \mathrm{~g}$ vs. $2750 / 2650 \mathrm{~g}, 40$. hét $3065-3187 / 3058-$ $2977 \mathrm{~g}$ vs. $3550 / 3400 \mathrm{~g}$ ) [32]. A percentilisgörbék lefutása azonban ezekben a populációkban is a miénkhez hasonlóan exponenciális jellegû.

\section{Ikerszülések adatai nemzetközi összehasonlitásban}

Ikrek születési testtömegére vonatkozóan lényegesen kevesebb irodalmi adat áll rendelkezésre. A korábban bemutatott dél-koreai vizsgálatban (2010 és 2012 között, $\mathrm{n}=42314$ újszülött) többes terhességekból született magzatokat is vizsgáltak [31]. A 36-39. gesztációs hét kivételével a fiúk és a lányok esetében is nagyobb a többes terhességekból született magzatok testtömege az általunk megfigyelthez viszonyítva (24. hét: $713 / 664 \mathrm{~g}$ vs. $666 / 350 \mathrm{~g}$, 28 . hét: $1198 / 1124 \mathrm{~g}$ vs. $1140 / 1060 \mathrm{~g}$, 32. hét: $1833 / 1739 \mathrm{~g}$ vs. $1830 / 1705 \mathrm{~g}, 36$. hét: $2479 / 2382$ g vs. $2480 / 2400$ g, 40 . hét: $2946 / 2880$ g vs. $2928 / 2775 \mathrm{~g}$ ). A percentilisgörbék alakja a mi eredményeinkhez hasonlóan inkább lineáris jellegú. Tajvanban ugyanakkor egy korábbi (1998 és 2002 közötti) időszakban vizsgálva az iker magzatoknál zömében a mi eredményeinknél kisebb magzati születési súlyokat találtak [33].

Indiában (1991 és 2005 között, csaknem 9000 újszülött) a monochorialis és bichorialis ikrek születési testtömegét hasonlították össze. A monochorialis ikrek percentilisgörbéi az egyes terhességekéhez hasonló exponenciális, míg a bichorialis ikrek görbéi az általunk talált lineáris lefutásúak [34]. Az ikrek születési súlya alacsonyabb volt az egyes terhességből született magzatok születési súlyánál, ami hasonló a mi eredményeinkhez.

Egy kínai vizsgálatban (2006 és 2015 között, $\mathrm{n}=$ 22507 élveszülött iker) a születési súlyok a magyarországi adatokhoz hasonlóak, talán a hazai iker újszülöttek a terminusban valamivel nagyobbak (28. hét: 1200/1130 $\mathrm{g}$ vs. $1140 / 1060 \mathrm{~g}, 32$. hét: $1800 / 1700 \mathrm{~g}$ vs. $1830 / 1705$ g, 36. hét: fúk $2500 / 2400$ g vs. $2480 / 2400$ g, 40. hét: $2770 / 2660 \mathrm{~g}$ vs. $2928 / 2775 \mathrm{~g}$ ) [35]. Érdekes, hogy a kínai percentilisgörbék az ikreknél is inkább exponenciális jellegúek és nem lineárisak.

\section{A születési súlyok temporális trendje}

A 2011 és 2015 közötti időszak mellett vizsgáltuk a korábbi ötéves időszakok átlag születési súlyait is a referencia-idószakhoz viszonyítva. Az egyes terhességekben fiúknál a 37-39. héten, lányoknál a 36-38. héten szignifikáns heterogenitást találtunk. Általánosságban megállapítható, hogy az érett szüléseknél az átlagos születési súly emelkedett 2006-2010-ig, majd 2011-2015 között csökkent. Ikreknél hasonló tendenciát (valószínúleg részben a kisebb statisztikai erő miatt) nem sikerült igazolni.

Amerikai szerzók a magyarországi eredményekhez hasonlóan az érett szülésekból született magzatoknál az utóbbi években csökkenő születési súlyt találtak. Ennek hátterében a gyakoribb (vagy a diagnosztika fejlődése miatt gyakrabban igazolt) patológiás terhességek miatti szülésindukciók vagy szülésbefejezések állhatnak [36]. Ausztrál szerzők a magzatok születési súlyát 1998 és 2007 között viszonylag stabilnak találták [37], hasonlóan vietnami szerzők 2005 és 2012 közötti adataihoz [38] és dél-koreai adatokhoz [31]. Érdekesség, hogy míg saját eredményeink hasonlóak voltak a döntő́n kaukázusi lakosságú, fejlett országok hasonló időszakában megfigyeltekhez, az időbeli trendek a világ különböző országaiban eltérőnek bizonyultak.

Az ikerszülésekre vonatkozó adatok a világ különböző részein eltérőek: Ausztráliában [39] és Kínában [40] az ikrek születési súlya az utóbbi években csökkent, míg Dél-Koreában emelkedố tendenciát írtak le a 37. gesztációs hét után [31]. Saját adataink is ez utóbbi trendeket mutatják: az érett ikrek születési testtömege az utóbbi 20 évben összességében növekedett.

A gesztációs hetekhez tartozó születési súly percentilisértékeinek ismerete nemcsak szülészeti, hanem neonatológiai, gyermek-, sőt felnőttgyógyászati szempontból is igen jelentős. Az alacsony születési súlyú (SGA-) magzatok méhen belüli növekedési elmaradása növeli a perinatalis mortalitás, morbiditás rizikóját [41]. Ezek az újszülöttek gyakrabban szenvednek hypoglykaemiától, respiratorikus distressztől, hypothermiától, nekrotizáló enterocolitistől és retinopathiától [42]. Gyermek- és fiatal felnőtt korban hormonális problémák (korai adrenarche és polycystás ovarium szindróma) és az alacsony növés jelenthet problémát [43-46], felnőttkorban pedig szignifikánsan gyakoribb köztük a hypertonia, az elhízás, a dyslipidaemia, a 2 -es típusú diabetes és a cardiovascularis betegségek előfordulása [41, 47]. Ugyanakkor a túlzott magzati növekedés (LGA) is fokozott kockázattal jár a gyermek egész életében: gyakoribbak a szülés alatti komplikációk (vállelakadás, elhúzódó szülés, császármetszés), a magzati morbiditás és a késői kardiometabolikus megbetegedések [48].

\section{A vizsgálat erôsségei}

A Tauffer-statisztika, a fegyelmezett és jól múködő adatgyújjtésnek köszönhetően, csaknem az összes hazai szü- 
lésről tartalmaz adatot. Az adatbázis 92,4\%-os kitöltöttsége mellett eredményeinket populációs szinten reprezentatívnak tekinthetjük [19]. Bár a rendszerből hiányzó szülések eredményei potenciálisan torzításhoz vezethetnek, nem áll ezekról rendelkezésre adat, így a hiányzó adatok imputációja sem lehetséges. A nemzetközi irodalomhoz hasonlóan a hibás adatbevitelek, illetve az extrém patológiás terhességek torzító hatásának kiszürésére nemenként az egyes gesztációs hetek extrém súlyértékeit kizártuk, ezt követően a percentilisgörbék lefutása simává vált.

Eredményeink klinikai haszna nyilvánvaló: a szülészek és a nőgyógyászok a nem és gesztációs hét szerint az egyes és ikerterhességekből született magzatokat születési súlyuk alapján átlagos (25-75 percentilis), átlag alatti és feletti (10-25 és 75-90 percentilis), illetve SGA- és LGA- (<10 és >90 percentilis) csoportokba sorolhatják, ami a magzatok további ellátását is befolyásolja.

\section{A vizsgálat korlátai}

Bár a szülések utáni adatkitöltés kötelező, ez sajnos mégsem történik meg minden esetben. Az adatok pontosságát és teljességét rendszeres minőségbiztosítás nem felügyeli. Amennyiben az egyes szülészeteken a testsúly mérése során a random hiba mellett torzítás is fellép, ez az általunk publikált percentilisadatok szisztémás hibáját okozhatja. Megjegyzendő azonban, hogy a súly az antropometriai adatok közül a legkevésbé érzékeny a torzításra, és a szülészeti osztályoknak is alapvető érdekük a mérések minőségbiztosítása, amire az egészségügyi törvény is kötelezi az ellátókat. Ugyanakkor mindaddig, amíg standardizált, külső minőségbiztosítással végzett, reprezentatív felmérés során pontosabb adatok nem állnak rendelkezésre, úgy gondoljuk, hogy a jelen elemzés percentilisadatai jellemzik a legjobban a hazai születési súlyok terhességi kor és nem szerinti eloszlását.

A várandóssági kor pontos ismeretének eredetére sincs az adatbázisban megfelelő adat. A modern szülészetben a terhességi kor alapja az első trimeszterben a 10. és 14. hét között mért CRL, amire hazai javaslat és szakmai irányelv is felhívja a figyelmet. Az adatbázisban nem szerepel, honnan ered a terhességi kor pontos ismerete, azonban tekintettel arra, hogy a szakmai irányelvek ismerete és megfelelő alkalmazása minden nőgyógyász tevékenysége során elengedhetetlen, a feldolgozás során feltételeztük, hogy a terhességi kor pontosan került megjelölésre. A gesztációs kor pontos meghatározása azért is rendkívül fontos, mivel a hivatalos iratokra (szülészeti és neonatológiai kórlap, a Központi Statisztikai Hivatal lapja) kerülésén kívül a született magzat további obszervációját és kezelését is befolyásolja.

Bizonyos anyai paraméterek (például várandósság előtti testsúly, testmagasság, súlygyarapodás, dohányzási szokások, etnikai hovatartozás, szociális körülmények) figyelembevételével egyénre szabott percentilisértékek megadása is lehetséges volna, ami szorosabb összefüg- gést mutathat a szülés körüli szövődményekkel $[49,50]$. Az esetszám növelése lehetséges volna a referencia-időszak kiterjesztésével. Ha nem csak 5 évet, hanem ennél hosszabb periódust dolgozunk fel, a percentilisgörbék simábbak lehetnének, ugyanakkor a kapott percentilisgörbék lefutását a megfigyelt temporális trendek figyelmen kívül hagyása torzítaná. Vizsgálatunkban igyekeztünk a két versengő szempont optimális kezelésére. A 22-23. és a 42-43. hét összevonása a szülések kis száma miatt mindenképpen szükséges volt, így a percentilisértékek jól használhatók maradtak. A percentilisgörbéket nem simítottuk el, mivel a nyers adatok véleményünk szerint jobban tükrözik a valóságot. Az ikerterhességekből származó percentilisgörbék az egyes terhességekhez viszonyítva még kevésbé egyenletesek, de így is klinikailag megfelelően pontosak és jól használhatók.

Az esetszámokat, az átlagsúlyokat és az egyes terhességi hetek percentilisértékeit táblázatokban is összefoglaltuk, melyeket készséggel bocsátunk az érdeklődők rendelkezésére.

Anyagi támogatás: A közlemény megírása anyagi támogatásban nem részesült.

Szerzői munkamegosztás: Zs. L.: A kézirat és a számítások elkészítése, javítása. T. Gy. Á.: A PhD-vezető, a cikk és az ábrák elkészítésében vett részt. Cs. M. Gy.: Az adatokat rendelkezésre bocsátotta, tanácsadó a cikk és az ábrák elkészítésében. V. Gy.: Tanácsadó a cikk és az ábrák elkészítésében. A cikk végleges változatát valamennyi szerző elolvasta és jóváhagyta.

Érdekeltségi nyilatkozat: A szerzőknek a cikk eredményeivel kapcsolatban nincs érdekeltségük.

\section{Irodalom}

[1] Malin GL, Morris RK, Riley R, et al. When is birthweight at term abnormally low? A systematic review and meta-analysis of the association and predictive ability of current birthweight standards for neonatal outcomes. BJOG 2014; 121: 515-526.

[2] Vashevnik S, Walker S, Permezel M. Stillbirths and neonatal deaths in appropriate, small and large birthweight for gestational age fetuses. Aust N Z J Obstet Gynaecol. 2007; 47: 302-306.

[3] Kézmárszky T. About the weight changes of mature newborns. [Über die Gewichtsveränderungen reifer Neugeborener.] Arch Gynäkol. 1873; 5: 547-561. [German]

[4] Kontsek B. (ed.) Body sizes and proportions of newborns. [Újszülöttek méretei és testarányai.] Városi Nyomda, Debrecen, 1936. [Hungarian]

[5] Lubchenco LO, Hansman C, Dressler M, et al. Intrauterine growth as estimated from liveborn birth-weight data at 24 to 42 weeks of gestation. Pediatrics 1963; 32: 793-800.

[6] Battaglia FC, Lubchenco LO. A practical classification of newborn infants by weight and gestational age. J Pediatr. 1967; 71: 159-163.

[7] Bazsó, J Vachter, J Lányi I. The normal human birthweight gain and variations between 24 and 42 weeks. [A normális humán 
magzati súlynövekedés és variációi a 24-42. terhességi hetekben.] Magy Nôorv L. 1968; 31: 405-411. [Hungarian]

[8] Fekete M, Igazi K, Járai I, et al. The fetal weight gain in the third trimester. [A magzat növekedése a harmadik trimenonban.] Gyermekgyógyászat 1968; 19: 181-197. [Hungarian]

[9] Joubert K. The birth weight and its percentile curves according to girl and boy newborn livebirth data between 1973 and 1978 in Hungary. In: Lampé L. (ed.) University textbook of obstetrics and gynecology. [Születési súly és születési súly percentilis görbék hazánkban 1973-78 között élveszületett fiú- és leányújszülöttek adatai alapján. In: Lampé L. (szerk.) Szülészet-Nőgyógyászat egyetemi tankönyv.] Medicina Könyvkiadó, Budapest, 1981; pp. 525-528. [Hungarian]

[10] Joubert K. Birth weight and birth length standards on basis of the data of infants born alive in 1973-1978. Res Reports Demogr Res Inst. 1983; 12: 46.

[11] Joubert K. Birth weight and length standards on the basis of the data of infants born alive in 1973-1978. [A születési súly és születési hossz standard az 1973-1978. évben élveszületett újszülöttek adatai alapján.] Demográfia 1983; 26: 107-139. [Hungarian]

[12] Papp Cs, Szabó Gy, Papp Z, et al. Fetal growth rate and its variations in 1988/89. [A magzati súlynövekedés üteme és variációi 1988/89-ben.] Orv Hetil. 1991; 34: 1865-1870. [Hungarian]

[13] Boruzs K, Damjanovich P, Jakab A. Did the birthweight percentiles change in the recent decades? [Változtak-e a születési súlypercentilek az elmúlt évtizedekben?] Magy Nőorv L. 2014; 77: 98. [Hungarian]

[14] Csákány MGy, Konczwald L. New Hungarian newborn birthweight standard for opinion of intrauterine retardation and macrosomy. In: Cseh I. (ed.) The current theoretical and practical questions of obstetrics and gynecology. [Új hazai újszülött standard az intrauterin retardáció és a macrosomia megítélésére. In: Cseh I. (szerk.) A szülészet-nőgyógyászat aktuális elméleti és gyakorlati kérdései.] A Haynal Imre Egészségtudományi Egyetem Orvostovábbképző Kar Szülészeti és Nőgyógyászati Klinika kiadványa, 1998; pp. 19-26. [Hungarian]

[15] Joubert K. Hungarian newborn weight and length stardards according to national livebirth data in 1990-1996. [Magyar születéskori testtömeg- és testhossz-standardok az 1990-1996. évi országos élveszületési adatok alapján.] Magy Nőorv L. 2000; 63: 155-163. [Hungarian]

[16] Joubert K, Zsákai A, Berkő P. The newborn body weight, length and BMI standards according to national livebirth data between 2000 and 2012 in Hungary. [Születéskori testtömeg-, testhosszés BMI-standardok a 2000-2012. évi országos élveszületési adatok alapján, Magyarországon.] Demográfia 2015; 58: 173-196. [Hungarian]

[17] Erdei G, Kovács VA, Bakacs M, et al. Hungarian Diet and Nutritional Status Survey 2014. I. Nutritional status of the Hungarian adult population. [Országos Táplálkozás és Tápláltsági Állapot Vizsgálat 2014. I. A magyar felnőtt lakosság tápláltsági állapota.] Orv Hetil. 2017; 158: 533-540. [Hungarian]

[18] Hales CM, Fryar CD, Carroll MD, et al. Trends in obesity and severe obesity prevalence in US youth and adults by sex and age, 2007-2008 to 2015-2016. JAMA 2018; 319: 1723-1725.

[19] Zsirai L, Csákány GyM, Vargha P, et al. Breech presentation: its predictors and consequences. An analysis of the Hungarian Tauffer Obstetric Database (1996-2011). Acta Obstet Gynecol Scand. 2016; 95: 347-354.

[20] Zsirai L, Csákány MG, Tabák ÁG, et al. Increasing tendency of pregnancies complicated pregestational and gestational diabetes in Hungary between 1997 and 2006: analysis of the database of the National Inststitute of Obstetrics and Gynecology. [Praegestatiós és gestatiós diabetesszel szövődött terhességek növekvő gyakorisága Magyarországon 1997-2006 között: az Országos Szülészeti és Nőgyógyászati Intézet adatbázisának validálása és elemzése.] Diabet Hung. 2011; 19: 125-134. [Hungarian]
[21] Hungarian Central Statistical Office. Tables of data. [Központi Statisztikai Hivatal. Adattáblák]. Available from: http://www. ksh.hu/docs/hun/xstadat/xstadat_hosszu/h_wdsd00la.html [accessed: April 27, 2019]. [Hungarian]

[22] Robinson HP. Sonar measurement of fetal crown-rump length as means of assessing maturity in first trimester of pregnancy. $\mathrm{Br}$ Med J. 1973; 4(5883): 28-31.

[23] ISUOG practice guidelines: performance of first-trimester fetal ultrasound scan. Ultrasound Obstet Gynecol. 2013; 41: 102113.

[24] Health Professional College. Healthcare professional guideline for the early and basic ultrasound screening. Clinical healthcare professional policy 2017. [Egészségügyi Szakmai Kollégium. Egészségügyi szakmai irányelv a koraterhességi diagnosztikus és az alap (basic) ultrahang szứrővizsgálatokról. Klinikai egészségügyi szakmai irányelv 2017.] Available from: https://kollegium. aeek.hu/Iranyelvek/Index [accessed: April 27, 2019]. [Hungarian]

[25] Stirnemann J, Villar J, Salomon LJ, et al. International estimated fetal weight standards of the INTERGROWTH-21st Project. Ultrasound Obstet Gynecol. 2017; 49: 478-486.

[26] Pawlus B, Wiśniewski A, Kubik P, et al. Birth body length, birth body weight and birth head circumference in neonates born in a single centre between 2011 and 2016. Ginekol Pol. 2017; 88: 599-605.

[27] Topçu HO, Güzel AI, Özgü E, et al. Birth weight for gestational age: a reference study in a tertiary referral hospital in the middle region of Turkey. J Chinese Med Assoc. 2014; 77: 578582.

[28] González González NL, González Dávila E, García Hernández JA, et al. Construction of model for calculating and recording neonatal weight percentiles. An Pediatr (Barc). 2014; 80: 81-88.

[29] Duryea EL, Hawkins JS, McIntire DD, et al. A revised birth weight reference for the United States. Obstet Gynecol. 2014; 124: 16-22.

[30] Martínez PA, Díaz P, Romero A, et al. New references for neonatal weight by gestational age and sex, Holguín, Cuba. MEDICC Rev. 2015; 17: 18-22.

[31] Lee JK, Jang HL, Kang BH, et al. Percentile distributions of birth weight according to gestational ages in Korea (20102012). J Korean Med Sci. 2016; 31: 939-949.

[32] Kumar VS, Jeyaseelan L, Sebastian T, et al. New birth weight reference standards customised to birth order and sex of babies from South India. BMC Pregnancy Childbirth 2013; 13: 38.

[33] Hu IJ, Hsieh CJ, Jeng SF, et al. Nationwide twin birth weight percentiles by gestational age in Taiwan. Pediatr Neonatol. 2015; 56: 294-300.

[34] Premkumar P, Antonisamy B, Mathews J, et al. Birth weight centiles by gestational age for twins born in south India. BMC Pregnancy Childbirth 2016; 16: 64.

[35] Zhang B, Cao Z, Zhang Y, et al. Birthweight percentiles for twin birth neonates by gestational age in China. Sci Rep. 2016; 6: 31290.

[36] Catov JM, Lee M, Roberts JM, et al. Race disparities and decreasing birth weight: are all babies getting smaller? Am J Epidemiol. 2016; 183: 15-23.

[37] Dobbins TA, Sullivan EA, Roberts CL, et al. Australian national birthweight percentiles by sex and gestational age, 1998-2007. Med J Aust. 2012; 197: 291-294.

[38] Duong DM, Nguyen AD, Nguyen CC, et al. A secular trend in birth weight and delivery practices in periurban Vietnam during 2005-2012. Asia Pac J Public Health 2017; 29(5 Suppl): 18S$24 \mathrm{~S}$.

[39] Li Z, Umstad MP, Hilder L, et al. Australian national birthweight percentiles by sex and gestational age for twins, 20012010. BMC Pediatr. 2015; 15: 148. 
[40] Liu Q, Yu C, Gao W, et al. Change trend of birth weight of twins in China, 1995-2012. Zhonghua Liu Xing Bing Xue Za Zhi 2015; 36: 115-118.

[41] Chernausek SD. Update: consequences of abnormal fetal growth. J Clin Endocrinol Metab. 2012; 97: 689-695.

[42] Lim JS, Lim SW, Ahn JH, et al. New Korean reference for birth weight by gestational age and sex: data from the Korean Statistical Information Service (2008-2012). Ann Pediatr Endocrinol Metab. 2014; 19: 146-153.

[43] Itabashi K, Mishina J, Tada H, et al. Longitudinal follow-up of height up to five years of age in infants born preterm small for gestational age; comparison to full-term small for gestational age infants. Early Hum Dev. 2007; 83: 327-333.

[44] Karlberg J, Albertsson-Wikland K. Growth in full-term small-forgestational-age infants: from birth to final height. Pediatr Res. 1995; 38: 733-739.

[45] Hernández MI, Mericq V. Impact of being born small for gestational age on onset and progression of puberty. Best Pract Res Clin Endocrinol Metab. 2008; 22: 463-476.

[46] Ibáñez L, López-Bermejo A, Díaz M, et al. Early metformin therapy (age 8-12 years) in girls with precocious pubarche to reduce hirsutism, androgen excess, and oligomenorrhea in adolescence. J Clin Endocrinol Metab. 2011; 96: E1262-E1267.

[47] Barker DJ. Outcome of low birthweight. Horm Res. 1994; 42: 223-230.

[48] Clausen TD, Mathiesen ER, Hansen T, et al. High prevalence of type 2 diabetes and pre-diabetes in adult offspring of women with gestational diabetes mellitus or type 1 diabetes: the role of intrauterine hyperglycemia. Diabetes Care 2008; 31: 340-346.

[49] Agarwal P, Rajadurai VS, Yap F, et al. Comparison of customized and cohort-based birthweight standards in identification of growth-restricted infants in GUSTO cohort study. J Matern Fetal Neonatal Med. 2016; 29: 2519-2522.

[50] McCowan L, Stewart AW, Francis A, et al. A customised birthweight centile calculator developed for a New Zealand population. Aust N Z J Obstet Gynaecol. 2004; 44: 428-431.

(Zsirai László dr., Budapest, Völgy u. 25/A, 1021 e-mail: zslaci02@t-online.hu)

\section{"Propositum mutat sapiens, et stultus inhaeret." \\ ( $A$ bölcs megváltoztatja véleményét, az ostoba makacsul ragaszkodik hozzá.)}

